\title{
Exploring Entrepreneurship Policy in a Pacific Context: The Case of Tonga
}

\begin{abstract}
In 2010, data was collected to explore entrepreneurship in a Pacific context. The preliminary conceptual model is based on the triangulation of findings from the National Expert (NES) and Adult Population (APS) components of the Global Entrepreneurship Monitor (GEM). For the NES, 25 national experts were interviewed in order to understand the factors that constrain and promote entrepreneurial activity. The APS analyzed the responses of 1184 household members across Tonga regarding their actual experiences and perceptions of entrepreneurial activity. Our analysis uses grounded theory in tandem with this model because of the lack of tested theory regarding entrepreneurship in the Pacific. The NES data was initially used in the analysis, and the triangulated confirmatory findings from the APS were used once the emergent propositions had become clear. Seven new propositions are developed that extend our existing conceptualization of entrepreneurship. The research implications and limitations are discussed.
\end{abstract}

Key Words: Tonga, Entrepreneurship, GEM. 


\section{Introduction}

The aim of this paper is to explore entrepreneurial behavior in Tonga. Our main aim is to start the theory development process regarding the proposition that, in the Pacific, there is a specific model of entrepreneurship. We believe that this research could have wider implications for the Pacific and become a model for entrepreneurial behavior, one that builds on traditional conceptualizations such as the Global Entrepreneurship Monitor (GEM) project.

This aspiration is important because it is widely understood and accepted that entrepreneurship raises the living standards of developing and developed countries (Cahn, 2008; Ayyagari, Beck and Demirgue-Kunt, 2003) by creating small to medium sized enterprises (SME's) that contribute economically to their owners, collectives and society. However, there is no guarantee that entrepreneurship will enhance the economic development of a nation (Autio, Kronlund \& Kovalainen, 2007).

Despite the existent knowledge about the relationship between entrepreneurship and economic development, there is a dearth of evidence from the Pacific region (Saffu, 2003; Yusuf, 1995). Since, Yusuf (1995), few studies have been completed. Yusuf (1998) explored SME’s in six developing countries in the South Pacific and concluded that the key issues facing entrepreneurs in the Pacific included; finance, deficient industry and market information, poor business knowledge and planning skills, infrastructure barriers, and the impact of culture on entrepreneurship. Cahn (2008) supported these findings in an exploration of the synergy and tensions in the relationship between fa'aSamoa and micro-entrepreneurial activity. Saffu (2003) agreed, arguing that Pacific Island entrepreneurs are different from Western entrepreneurs.

Therefore, the key research objective governing this study is to explore and understand entrepreneurial behavior in Tonga (Saffu, 2003). Because of the lack of current knowledge to 
answer the research question, an exploratory approach is taken that transverses the traditional boundaries between firm, consumer and environment (Gummesson, 1999; Lindberg-Repo and Grönroos, 1999; Fournier, 1998). Emphasis is placed on observing the phenomenon in its natural setting by grounding the knowledge development process and direction in real world phenomena. What is learnt is then related to the existing streams of the theory of entrepreneurship and other disciplines as a means of further building the conceptual representation. This tandem approach enables the researcher to shift back into the setting with a more valid understanding of the emerging theory, thus allowing for further empirical model refinement and development.

Before a more in-depth specification of the research strategy is outlined, it is important to explain why an alternative approach has been applied to answer the research question. It differs from the traditional approach, which begins with the development of a problem orientation, continues with the literature review, states the hypotheses and finally tests and discusses them through data collection and analysis. Hunt (1991) shows an extensive knowledge of this traditional approach to modern, positivist marketing theory development. However, in marketing research which challenges this dominant philosophy, significant debate rages concerning the appropriate method and philosophical approach that should be applied to generate scientific theory (Hunt, 1991). Characteristic of this debate is the position of Hunt and Monieson (1989, p. 4) vs. Monieson (1988) and Dholakia (1988), who “attack positivism and positivistic social science that...dominate contemporary...social science.”

The debate extends to methodological issues that reflect the dichotomy between quantitative (positivistic) and qualitative (relativistic) approaches (Coviello, 1999). Hunt (1991) and Peter and Olson (1983) provide an extensive comparison between the two philosophical orientations. 
For example, Hunt (1991, p. 398) seems to promote the former orientation, but he is led to conclude "that no single philosophy dominates" (see also Downey and Ireland, 1979).

This debate highlights two key issues. The first relates to what good theory is and the implications for research method. The second demands that researchers clearly state their research philosophy and context so that individual readers can understand both the conceptual foundation and the direction of the research, thus gaining a deeper understanding of its external validity. This is particularly important where the goal of the research is to explore rather than to generalize. Therefore, it is not the desire of the researchers to become embroiled in what Orlikowski and Robey (1991) and Brodie (1999) have defined as the persistent debate surrounding false and dangerous dichotomies (subjective versus objective, socially constructed versus material, macro versus micro, and qualitative versus quantitative). Instead, attention is given to the position and philosophy of the scientific approach that is applied in this research.

This can be best described as a case study using grounded theory as the mode of analysis. We also triangulate these results with the findings from a quantitative study of the country's adult population. The research benefits from both approaches because, since no existent theory is present, the conceptual development process is grounded in the mode and context of analysis. At the same time limited positivistic direction and guidance is provided by the literature, which is utilized before and during the data analysis. Further clarification is also provided by the results of the APS study. Once the emergent theory becomes clear, greater attention is given to developing an objective theory that is generalisable to other research settings. Therefore, while we will present a preliminary conceptual model, most of our theory development will emerge from our data analysis in accordance with_the grounded theory approach. 
This research will contribute in three ways. Conceptually, this study will develop a model of entrepreneurship in the Pacific as a valid basis for theory development. Empirically, we bring two sets of data to support and help explore this proposition. Finally, managerial implications are developed through the interpretation of the findings from a policy perspective.

The paper progresses through a discussion of the underlying guiding conceptualization to the method and a discussion of the key findings. The final discussion focuses on proposition development with the aim of developing some form of conceptualization of entrepreneurship in a Pacific context.

\section{Conceptual Model}

The Global Entrepreneurship Monitor (GEM) focuses on three main objectives (GEM, 2010). The first one is to measure the level of social and business entrepreneurship among countries (e.g., De Clercq and Bosma, 2008, de Waal, 2004). The aim of the second is to uncover the factors determining national levels of entrepreneurial activity, while the intention of the third is to identify policies that may enhance the level of social and business entrepreneurial activity (Koellinger, Minniti and Schade, 2007).

GEM defines entrepreneurship as any attempt at a new business or social enterprise by an individual, teams of individuals, or established businesses or social enterprises. Traditional analyses of economic growth tend to focus on established firms in the commodities, manufacturing, service or knowledge sectors. GEM considers not only the economic contribution of large and small businesses and social enterprises but also the behavior of the individuals behind them (e.g., Langowitz and Minniti, 2007).

GEM links a country's economic activity to the interplay between established and new firms (Aidis, Estrin and Mickiewicz, 2008). It thus allows a clearer understanding of why 
entrepreneurship is vital to the whole economy. GEM adopts the Porter's typology of "factordriven economies", efficiency-driven economies" and "innovation-driven economies” (Porter, Sachs, \& McArthur, 2002). In this context, factor-driven economies are typically extractive in nature, meaning that the majority of their production is extracted primarily from the land's natural resources (mining, agricultural and fisheries) as opposed to manufactured products. In this category, getting the basic requirements right is the key to the generation of sustainable businesses that can contribute to not just local economic activity but to the health and education of the next generation (GEM, 2010, p. 11). Therefore, the emphasis is on the development of institutions, infrastructure, macroeconomic stability, healthcare and primary education. Tonga identifies with such an economy.

The GEM conceptual model, methodology and data are widely published and are currently being deployed by 57 countries. There are two components to the GEM conceptual model. (1) The Adult Population Survey (APS) classifies the respondent as a start-up entrepreneur, an established business owner, a start-up social entrepreneur, or an established manager of a social enterprise, as well as the proportion of the total population. (2) The National Expert (NES) component focuses on the factors that constrain entrepreneurial activities and the factors that promote entrepreneurship, and recommend areas that can be improved in promoting entrepreneurship (Tajnikar and Pusnik, 2008; Lee and Wong, 2004). 


\section{Methodology}

\section{Adult Population Survey (APS)}

The APS questionnaire is based on an annually reviewed survey instrument that relates to several kinds of individual involvement in entrepreneurial activity and attitudes to entrepreneurial activity. The questionnaire was translated into Tongan by a language expert and the total number of 1184 responses was collected across Tonga. It was then back-translated by the National Project Director. Finally, our bilingual enumerators went over the translation with a fine-toothed comb over four days of training.

The National Project Director had extensive research and evaluation experience as well as incountry expertise in project management, relationship development, administration, facilitation, financial management, cultural protocols, translation, public relations, risk management and data collection. A team of experienced enumerators were recruited with the support of the Department of Statistics and further trained over a four-day period to accept the formal responsibility of collecting the data. There was a "soft-launch" in Tonga and all the systems were evaluated. After that, a full national survey was conducted, and enumerators flew or travelled by boat to their assigned destinations over a two-week period.

The quality of work done by the interviewers was maintained by an effective system of fieldwork supervision. Each supervisor was responsible for a small number of interviewers and checked the quality of their work. Interviewers used a short checklist to go over their completed questionnaires to ensure that the basic rules for completing the interviews were being followed in every surveyed household. Each survey questionnaire was checked with respect to the items on this list and was signed by the supervisor and the interviewer. The National Project Director made spot checks to observe the interviewer while he or she was interviewing a household to 
verify that the interviewer was following all the procedures taught in the training. At the end, the Principal Investigator examined and approved all the surveys, and personally scanned all of them. Data from the field were immediately sent back to administration and prepared for data entry.

\section{National Expert Study (NES)}

The NES has two components: (1) Face-to-face interviews and (2) a 97-item empirical questionnaire using the Likert items that play a crucial role in the success of GEM. These results provide a qualitative and quantitative overview of entrepreneurial activity that can be used in the development of policy recommendations that help increase entrepreneurship.

The questionnaire presents questions and statements about various factors of entrepreneurship. Each response is measured on a standardized scale, which increases the reliability of any differences identified within and among countries. The questionnaire provides standardized measures of expert opinions in each country. Experts are people who are directly involved in delivering or assessing a major aspect of an entrepreneurial framework condition in their country. Experts can be politicians, academics, entrepreneurs, government officials, or other professionals involved in the field of entrepreneurship. Therefore, experts are individuals with knowledge of entrepreneurship that could have resulted from various experiences and perspectives.

The sample includes: different genders; a variety of individuals who are either professionals or entrepreneurs; individuals with different expertise and experience relative to the original nine framework conditions; and individuals from various geographical locations covering national, regional, and local areas. The in-depth interviews and the additional quantitative surveys were carried out with individuals from both the public and private sectors. These individuals were 
canvassed from 9 categories, namely: financing, Government policies, Government programs, education, R\&D transfer, commercial and business services, internal market openness, social and cultural norms, and physical infrastructure.

\section{Analysis}

Our analysis was first guided by the National Expert component of the GEM and we also used grounded theory as the mode of analysis (Yin, 1994). Most emphasis was placed initially on the qualitative data from the NES. We use grounded theory in tandem with the GEM conceptual model because of the lack of tested theory regarding entrepreneurship in the Pacific and in particular, Tonga (Levie and Autio, 2008).

Grounded theory was employed by Glaser and Strauss (1967) to enable them to discover theory from data rather than having to proceed by quantitatively testing hypotheses derived from the work of a few specialized theorists (Strauss and Corbin, 1990). Miles and Huberman (1994) state that grounded theory fits into the social anthropology approach to qualitative data analysis; the emphasis is on the genesis or refinement of theory, and the conceptual framework emerges from the field in the course of the study. The grounded theory method is valid empirically because the process of conceptual development is bound to evidence and "grounded in the reality of experience” (Gummesson, 1999; Eisenhardt, 1989; 1991).

The data consists of the qualitative interviews of 25 'national experts' in Tonga. The ethnic groups of the interviewees included Tongans and expatriates. Operationally, the following process of analysis was applied. The 25 interview transcripts were prepared in verbatim. The analysis employed techniques advocated by Miles and Huberman (1994) and Yin (1994). A coding scheme was developed and emblematic vignettes were then associated with the emerging 
codes. Both researchers reviewed the process and the conclusions to ensure their validity, and AusAID also reviewed an interim report on the findings.

The qualitative data was analyzed using key themes. These were categorized based on the three thematic areas and on the ranking of the three main answers the participants were asked to identify and rank in order of priority. The key themes were factors limiting entrepreneurial activity; factors promoting entrepreneurial activities; and finally, areas to recommend for improvement. From these main themes, sub-themes also arose in relation to the different responses to the three main thematic areas. From the sub thematic areas, different variables were identified, which were specific responses to the sub-themes. The frequency of responses to each sub-thematic area and on the different variables was recorded by using a scorecard. The scoring was used in relation to and in alignment with what was identified in the both the National Adult Survey and in the National Expert Survey as the National Conditions Influencing Entrepreneurial Activity in Tonga. In this instance, Miles and Huberman's model of data reduction, data display and conclusions was used to analyze the emerging themes.

Triangulation of the results was then based on the three main thematic areas, the sub themes, and the National Conditions, which were adopted in the discussion of the implication of the findings. Also significant to this process of data analysis was ensuring that the methods used would accurately reflect the cultural values and meanings of the research participants and of the community being researched (Tamasese, Peteru and Waldegrave, 1997). Finally, collaboration, honesty and the empowerment of all stakeholders remains a cornerstone of this research. Where appropriate, Pacific methodology will also be used to reciprocate the findings of this project back to the researched community and it's people. One of the key findings that emerged from the NES 
analysis triangulation resulted from the quantitative results of the NES. Further confirmatory evidence also arose from the APS results from 1184 completed responses.

\section{Conceptualization and Discussion}

In the discussion, we link the key findings to the to the Kingdom of Tonga's National Strategic Planning Framework (NSPF). In addition, we develop propositions to further evolve the conceptual model.

The adult population findings concluded that while there is a high awareness of entrepreneurial activity at the early stages, the fear of failure contributes to low continuity of businesses. At a national level, current policy seeks to overcome this failure by the support of private sector growth through better engagement with government, appropriate incentives, and the streamlining of rules and regulations. Current activity is focused on the World Bank indicators 'ease of doing business' and Asian Development Bank initiatives. There is support of donor organizations like NZAid and AusAID as well as other institutions with related initiatives that will help to reduce the fear of failure and improve business continuity rates. Therefore we propose:

P1: Entrepreneurial activity in the Pacific is driven by 2 opposing dichotomies; awareness and the perception of failure.

In Tonga the adult population are equally motivated by necessity and having the opportunity to start up a new business. A reason for this seems to be the high media attention given to new businesses. In contrast, the level of motivation for established businesses is generally unchanged. Current national policy work, which includes facilitating community development by involving the district/village communities in meeting their service needs, can be one way of stimulating 
increased motivation across all stages of entrepreneurial activity in the island nation. Therefore, it is proposed:

P2: Entrepreneurial activity in the Pacific evolves through necessity and is sustained through collective and community structures.

In terms of the aspirations, investments and commitment of the adult population, the findings concluded that for new start-ups and established businesses, these characteristics/variables were not significant, particularly in relation to initial start investment capital. Significantly, much of the capital and labor came from family and the social collective. The respondents felt that there was insignificant interest shown from formal business angel investment. The relationships between investors and business start-ups were mainly family based, reflecting $62.2 \%$ of respondents. The GEM study ranked Tonga $2^{\text {nd }}$ for most people considering starting a business as desirable career choice. However, in reality, the results suggest that this did not necessarily translate into action due to key non-performing entrepreneurial conditions such as finance, research and development transfer. Alleviating this condition can be achieved by the realization of NSPF primary objectives 1 and 2: (1) make possible community development that is supported by various AusAID and NZAid projects in progress and (2) support private sector growth. Therefore, it is proposed:

P3: Entrepreneurial activity in the Pacific in terms of aspirations, investments and commitment is internalised by collectives and the community.

Just over half the adult population surveyed perceived markets and innovations in Tonga in a positive light, believing that products or services offered by new and established businesses are new. At a national level, improving entrepreneurial framework conditions via NSPF is a sign of 
strong commitment to small enterprises and the wider private sector. Streamlining of incentives and regulations would be encouraging and supportive of this ideal. Therefore, it is proposed:

P4: Entrepreneurial activity in the Pacific is framed by the internal perceptions about markets, products, services and other innovations.

The results show that according to $63 \%$ of the Tongan adult population respondents, business discontinuity is high after 12 months of business activity. (Lack of continuity is not a sign of failure in Tonga, according to the respondents.) A major reason for this attitude was the global recession, which the NSPF objectives are designed to address. Specifically they are met by increasing the performance of Technical Training Vocational Education and developing services and infrastructure.

Table 1. Here 
In support of NSPF, the findings suggest that national priorities should include designing financial packages and determining realistic lending criteria that will be mutually beneficial to all key stakeholders. Furthermore, increasing government programs aimed at introducing 'good governance principles' in local and regional governance and building local capability to participate in the overall decision-making process will encourage entrepreneurial activity and meet the objectives of NSPF.

In the findings, local experts suggested that specific education and training incentives will help build capability in areas deemed deficient, such as increasing the understanding of gaps in the market and promoting and transferring knowledge that will fill these gaps. However, Tongan experts stressed that local knowledge is vital as a means of understanding the service needs of the community at both village and regional levels, with infrastructure being a key challenge.

Some participants stated that enabling easy access to research findings for key stakeholders would support and strengthen the work of National Economic Development Council (NEDC), which should build capacity and capability within the public sector in order to provide improved commercial infrastructural services for the private sector. NSPF emphasizes maintenance and development in infrastructure as a way to improve the everyday lives of the Tongan people. The findings suggest that development should focus on improving: (a) access by sea and air to outer and remote islands (b) roads, basic utilities and waste disposal in rural and remote areas and (c) increased telecommunication coverage. This work is evident in Tonga today, being carried out by joint and collaborative ventures between Tonga, NZ, and Australia.

The NSPF promotes an increase in the performance of technical training and vocational education and training to meet the challenges of maintaining and developing services and infrastructure. Experts felt that the introduction to business studies and skills at primary and 
secondary level is a key approach to improving this condition. A current initiative being driven by the Asian Development Bank (ADB) and the World Bank (WB) is highlighted in the 'Doing Business' project. This effort focuses on objective measures of business regulations and their enforcement across 183 economies and selected cities at the sub- national and regional level. Some respondents argued that facilitating opportunities for scholarships, apprenticeships and overseas internships is another step towards supporting the NSPF.

Additionally, the NSPF is integrating environmental and climate change into all planning and executing of programs. The findings revealed that these objectives could best be met by including more content in the primary and secondary curriculum that is supportive of this ideal, although it should be driven by government policy. It should be clearly led by the public sector alongside NEDC, and adopted as a priority if it is to achieve the desired effect. Therefore, it is proposed:

P5: Entrepreneurial activity in the Pacific is a fundamental exchange for acquiring the benefits of specialised competencies (knowledge and skills) or services to create and maintain a service mindset and the co-creation of value in collectives and communities.

P6: The fundamental exchange hub for entrepreneurial activity in the Pacific is the collective and the community.

The enabling themes of NSPF include: a smaller, more efficient government so that resources can be transferred to the improvement of services and the maintenance of resources; better accountability by State Owned Enterprises for improved returns; improved revenue collection in order to achieve better conditions for stakeholders; and better cohesion of the government approach to donor funding. 
The experts stated that these themes can best be supported by (a) ensuring an alignment and clear linking of all government and private programmes, (b) a government policy designed to weed out corruption and unfair and illegal practices, and (c) establishing a centralized and effective system specifically for the purpose of monitoring projects, initiatives and programmes. Therefore, it is proposed:

P7: Entrepreneurial activity in the Pacific should be supported by processes that are communitybased, with support from the external processes of government and private organisations.

Table 2. Here

\section{Future Research and Limitations}

As suggested by the literature, there is little that is known about Pacific entrepreneurship. Future research can further develop the understanding of entrepreneurship as it relates to each individual Pacific island nation, thus providing a collective contribution to a relatively under-researched area in this discipline. Furthermore, the role of entrepreneurial women is significant in addressing some social and economic inequities. This position is particularly important to the South Pacific region, where understanding this phenomenon will be of great value in alleviating poverty.

Specifically, future research could focus on understanding the increasing role of women and entrepreneurship in Tonga. GEM Women’s Report (2007) highlights a call for research that investigates the relationship between factors at the country and national level and key indicators at the individual level (p.10). Additionally, researchers could conduct comparative studies of 
women's entrepreneurship in the Pacific islands for similarities or differences with a view to constructing a model for other developing Pacific nations, which could adopt them for their women-based enterprises. For instance, an exploratory study could be made comparing the VANWODs Mamas group in Vanuatu and the Women in Business group in Samoa.

The main limitation that constrains this research is the lack of literature on entrepreneurship in the Pacific. As Saffu (2003) and Cahn (2008) argue, the Pacific Island style is different. Hence, an exploratory rather than a confirmatory approach has been taken. There could be validity issues with the data as many of the interviews were conducted in Tongan and the translation into English could have altered the meaning of the text. However, the findings were verified by obtaining the services of an expert translator, and the translations were reviewed by one of the Tongan authors as well as an AusAID member with specific expertise in the Tongan context. 


\section{References}

Aidis, R., Estrin, S. and Mickiewicz, T. (2008) 'Institutions and Entrepreneurship Development in Russia: A Comparative Perspective', Journal of Business Venturing, Vol. 23, pp. 656-672.

Autio, E., Kronlund, M. and Kovalainen, A. (2007) 'High-Growth SME Support Initiatives in Nine Countries: Analysis, Categorization and Recommendations’, Report prepared for the Finnish Ministry for Trade and Industry.

Ayyagari, M., Beck, T. and Demirguc-Kunt, A. (2003) 'Small and Medium Enterprises across the Globe: A New Database', World Bank Policy Research Working Paper, No. 3127. Washington: World Bank.

Brodie, R.J. (1999) Editorial: Introduction to the special issue: Australian Marketing Journal, Vol. 7, No.1, pp.1-3.

Cahn, M. (2008) 'Indigenous Entrepreneurship, Culture and Micro-Enterprise in The Pacific Islands: Case Studies From Samoa', Entrepreneurship \& Regional Development, Vol. 20, No. 1, pp.1-18.

Coviello, N.E., McAuley, A. (1999) 'Internationalization and the smaller firm: a review of contemporary empirical research’, Manag. Int. Rev., Vol. 39, No. 3, pp. 223-256.

De Clercq, D. and Bosma, N.S. (2008) ‘An Exploratory Study of International Commitment by Nascent and Existing Firms', Journal of Small Business and Entrepreneurship, Vol. 21, No. 3, pp. 223-237.

Dholakja, N. (1988) 'Interpreting Monieson: Creative and Destructive Tendencies', Journal of Macromarketing, Vol. 8, No. Fall, pp.11-14. 
De Waal, A. (2004) 'Business Start-ups and Early-stage Entrepreneurship', International Journal of Entrepreneurship and Small Business, Vol.1, No. 3/4, pp.223-229.

Downey, H.K. and Ireland, R.D. (1979) 'Quantitative versus qualitative: Environmental assessment in organizational studies’, Administrative Science Quarterly, Vol. 24, pp. 630-637.

Eisenhardt, K.M. (1989) 'Building Theories from Case Study Research', Academy of Management Review, Vol. 14, No.4, pp.532-550.

Eisenhardt, K.M. (1991) 'Better Stories and Better Constructs: The Case for Rigor and Comparative Logic', Academy of Management Review, Vol.16, No.3, pp. 532-550.

Fournier, S.M. (1998) 'Consumers and their brands: developing relationship theory', Journal of Consumer Research, Vol. 24, pp. 343-73.

GEM (2010). Global Entrepreneurship Monitor. Obtained trough the Internet: http://www.gemconsortium.org/.

Global Entrepreneurship Monitor (2007). Report on Women and Entrepreneurship. Obtained trough the Internet: $\underline{h t t p: / / w w w . g e m c o n s o r t i u m . o r g / . ~}$

Glaser, B.G. and Strauss, A.L. (1967) 'The Discovery of Grounded Theory: Strategies for Qualitative Research’, New York: Aldine Publishing Company.

Gummesson, E. (1999) 'Total Relationship Marketing: Experimenting with a Synthesis of Research Frontiers’, Australasian Marketing Journal, Vol.7, No.1, pp.72-85.

Hunt, S.D. (1991) Modem Marketing Theory: Critical Issues in the Philosophy of Marketing Science. Cincinnati: South-Western Publishing Co. 
Hunt, S.D. and Monieson, D.D. (1989) 'Reification and Realism in Marketing: In Defense of Reason; Intellectualization in Macromarketing Revisited: A Reply to Hunt', Journal of Macromarketing, Vol.9, No.2, pp. 4-16.

Koellinger, P., Minniti, M. and Schade, C. (2007) 'I Think I Can, I Think I Can...: A Study of Entrepreneurial Behavior', Journal of Economic Psychology, Vol.28, pp.502-527.

Langowitz, N. and Minniti, M. (2007) 'The Entrepreneurial Propensity of Women', Entrepreneurship Theory and Practice, Vol. 31, No. 3, pp. 341-364.

Lee, L. and Wong, P.K. (2004) 'Cognitive Divergence among Entrepreneurship National Experts: Analysis of GEM Data 2000-2003', In: Zahra, et. al. (eds), Frontiers of Entrepreneurship Research 2004, (pp.620-634), Wellesley: Babson College.

Levie, J. and Autio, E. (2008) ‘A Theoretical Grounding and Test of the GEM Model’, Journal Small Business Economics, Vol.31, No. 3, pp. 235-263.

Lindberg-Repo, K. and Grönroos, C. (1999) 'Word-of-mouth referrals in the domain of relationship marketing', Australasian Marketing Journal, Vol. 7, No. 1, pp. 109-17.

Miles, M.B. and Huberman, M. (1994) Qualitative Data Analysis: An Expanded Sourcebook. Thousand Oaks: Sage Publications.

Monieson, D.D. (1988) ‘Intellectualization in Macromarketing: A World Disenchanted', Journal of Macromarketing, Vol.8, No. Fall, pp. 4-10.

Orlikowski, W. J. and Robey, D. (1991) Information technology and the structuring of organizations. Inform. Systems Res., Vol.2, pp.143-169.

Peter, J.P. and Olson, J.C. (1983) 'Is Science Marketing?' Journal of Marketing, Vol.47, No. Fall, pp. 111-125. 
Porter, M.E., Sachs, J.J. and McArthur, J. (2002) The Global Competitiveness Report 2001-2002. New York: Oxford University Press.

Saffu, K. (2003) 'The Role and Impact of Culture on South Pacific Island Entrepreneurs', International Journal of Entrepreneurial Behaviour \& Research, Vol.9, No.2, pp.55-73.

Smallbone, D. and Welter, F. (2004) Entrepreneurship in Transition Economies: Necessity or Opportunity Drive. Obtained through the Internet: www.babson.edu/entrep/fer/BABSON2003/XXV/XXV-S8/xxv-s8.htm [accessed 24 November 2010].

Strauss, A. and Corbin, J. (1990) Basics of Qualitative Research: Grounded Theory, Procedures, and Techniques. Newbury Park, CA: Sage Publications.

Tajnikar, M. and Pusnik, K. (2008) 'Determinants of Entrepreneurship in Slovenia from an International Perspective', In: Veloutson, C. (ed), Advances in Entrepreneurship Research (pp. 19-33), Athene: Atiner.

Tamasese, K., Peteru, C. and Waldegrave C. (1997) 'Ole Taeao Afua, The New Morning: A qualitative Investigation into Samoan Perspectives on Mental Health and Culturally Appropriate Services', Wellington: The Family Centre, Funded by the Health Research Council of New Zealand

Yin, R.K. (1994) Case Study Research. Thousand Oaks: Sage Publications.

Yusuf, A. (1995) 'Critical Success Factors for Small Business: Perceptions of South Pacific Entrepreneurs', Journal of Small Business Management, Vol.33, pp.68 -73.

Yusuf, A.B. (1998) 'Small Business Development and Survival in the South Pacific: Barriers and Strategic Responses', Journal of Entrepreneurship, Vol.7, No.1, pp.49-65. 
Tables 
Table 1. Adult Population Findings and National Strategic Planning Framework

\begin{tabular}{|c|c|c|c|c|c|}
\hline $\begin{array}{l}\text { ADULT } \\
\text { POPULATION } \\
\text { SURVEY } \\
\end{array}$ & FINDINGS & $\begin{array}{l}\text { TONGA'S GLOBAL } \\
\text { RANKING (GEM 2009) }\end{array}$ & RECOMMENDATIONS & $\begin{array}{l}\text { NATIONAL STRATEGIC PLANNING } \\
\text { FRAMEWORK (DRAFT) - PRIMARY OBJECTIVES }\end{array}$ & $\begin{array}{l}\text { CURRENT GOVERNMENT } \\
\text { AND DONOR ACTIVITY }\end{array}$ \\
\hline $\begin{array}{l}\text { Understanding } \\
\text { Entrepreneurship }\end{array}$ & $\begin{array}{l}\text { High awareness of } \\
\text { entrepreneurial activity at } \\
\text { early stages, but fear of } \\
\text { failure contributes to low } \\
\text { continuity of businesses. }\end{array}$ & $\begin{array}{l}\text { Ranked } 1^{\text {st }} \text { in the 'fear of failure' } \\
\text { rate. } \\
\text { Ranked } 16^{\text {th in }} \text { overall } \\
\text { entrepreneurial activity rate. }\end{array}$ & $\begin{array}{l}\text { Improve start up opportunities } \\
\text { and abilities and knowledge. } \\
\text { Improve support and training for } \\
\text { established businesses. }\end{array}$ & $\begin{array}{l}\text { This policy area supports Primary Objective 2: Support } \\
\text { private sector growth through better engagement with } \\
\text { government, appropriate incentives and streamlining of } \\
\text { rules and regulations. }\end{array}$ & $\begin{array}{l}\text { World Bank indicators 'ease of } \\
\text { doing business' } \\
\text { Asian Development Bank } \\
\text { initiatives } \\
\text { NZAid } \\
\text { AusAID } \\
\text { Tertiary Scholarships }\end{array}$ \\
\hline $\begin{array}{l}\text { Motivations to be } \\
\text { Entrepreneurial }\end{array}$ & $\begin{array}{l}\text { Tongans are motivated out } \\
\text { of necessity and having } \\
\text { the opportunity to start up } \\
\text { a new business. This is } \\
\text { also due to high media } \\
\text { attention given to new } \\
\text { business, but there is no } \\
\text { change in the level of } \\
\text { motivation for established } \\
\text { businesses. }\end{array}$ & $\begin{array}{l}50 \% \text { of sample driven by } \\
\text { opportunity as well as necessity } \\
\text { for nascent entrepreneurs. } \\
3^{\text {rd }} \text { in media attention for start } \\
\text { up businesses. }\end{array}$ & $\begin{array}{l}\text { Offer better support and } \\
\text { motivation for established } \\
\text { business owners, such as more } \\
\text { training programmes and } \\
\text { workshops. } \\
\text { Better governance and best } \\
\text { practice training. } \\
\text { Research and Development } \\
\text { Encourage interest in innovation. }\end{array}$ & $\begin{array}{l}\text { This policy area supports Primary Objective 1: Facilitate } \\
\text { Community Development by involving district/village } \\
\text { communities in meeting their service needs. } \\
\text { Primary Objective 2: Support private sector growth } \\
\text { through better engagement with government, appropriate } \\
\text { incentives and streamlining of rules and regulations. }\end{array}$ & \\
\hline $\begin{array}{l}\text { Aspirations } \\
\text { Investments and } \\
\text { Commitments }\end{array}$ & $\begin{array}{l}\text { Largely capital and labor } \\
\text { from family and the social } \\
\text { collective. }\end{array}$ & $\begin{array}{l}\text { Tonga ranked } 2^{\text {nd }} \text { in GEM } \\
\text { study for most people } \\
\text { considering starting a business } \\
\text { a desirable career choice. } \\
\text { Uganda ranked } 13^{\text {th }} \text { and } \\
\text { Jamaica } 15^{\text {th. }}\end{array}$ & $\begin{array}{l}\text { Improve access to finance. } \\
\text { Support social entrepreneurship. }\end{array}$ & $\begin{array}{l}\text { This policy area supports Primary Objective 1: Facilitate } \\
\text { Community Development by involving district/village } \\
\text { communities in meeting their service needs. }\end{array}$ & $\begin{array}{l}\text { Various AusAID and NZAid } \\
\text { projects }\end{array}$ \\
\hline $\begin{array}{l}\text { Markets and } \\
\text { Innovations }\end{array}$ & $\begin{array}{l}\text { More than half of sample } \\
\text { claim products or services } \\
\text { offered by new and } \\
\text { established businesses are } \\
\text { new }\end{array}$ & $\begin{array}{l}56.2 \% \text { new start ups. } \\
59.3 \% \text { established businesses. }\end{array}$ & $\begin{array}{l}\text { Strengthen interest in innovation. } \\
\text { Strengthen rights to intellectual } \\
\text { property. }\end{array}$ & $\begin{array}{l}\text { This policy area supports Primary Objective 2: Support } \\
\text { private sector growth through better engagement with } \\
\text { government, appropriate incentives and streamlining of } \\
\text { rules and regulations. }\end{array}$ & \\
\hline Business Angels & $\begin{array}{l}\text { Insignificant interest from } \\
\text { formal business angel } \\
\text { investment; mostly capital } \\
\text { from family members } \\
\end{array}$ & $\begin{array}{l}\text { The relationships between } \\
\text { investor and business start-up } \\
\text { were mainly family based - } \\
62.2 \% \text { of respondents } \\
\end{array}$ & $\begin{array}{l}\text { Create market openness. } \\
\text { Promote high growth. }\end{array}$ & $\begin{array}{l}\text { This policy area supports Primary Objective 2: Support } \\
\text { private sector growth through better engagement with } \\
\text { government, appropriate incentives and streamlining of } \\
\text { rules and regulations. }\end{array}$ & \\
\hline $\begin{array}{l}\text { Business } \\
\text { Discontinuity }\end{array}$ & $\begin{array}{l}\text { Discontinuity level high } \\
\text { after } 12 \text { months of } \\
\text { business activity. }\end{array}$ & $\begin{array}{l}\text { Less than two- thirds }(63 \%) \\
\text { exited due to global economic } \\
\text { recession. }\end{array}$ & $\begin{array}{l}\text { More programmes for established } \\
\text { businesses to sustain longevity. } \\
\text { Better financial packages to } \\
\text { support long-term growth. }\end{array}$ & $\begin{array}{l}\text { This policy area supports Primary Objective 5: Increase } \\
\text { performance of Technical Training Vocational Education \& } \\
\text { Training to meet the challenges of maintaining and } \\
\text { developing services and infrastructure. }\end{array}$ & $\begin{array}{l}\text { NZAid and AusAID tertiary } \\
\text { scholarships }\end{array}$ \\
\hline
\end{tabular}


Table 2. National Priorities and National Strategic Planning Framework

\begin{tabular}{|c|c|}
\hline & National Strategic Planning Framework \\
\hline $\begin{array}{l}\text { National } \\
\text { Vision }\end{array}$ & $\begin{array}{l}\text { "To create a society in which all Tongans enjoy higher living } \\
\text { standards and a better quality of life through good governance, } \\
\text { equitable and environmentally sustainable private sector-led } \\
\text { economic growth, improved education and health standards, and } \\
\text { cultural development". The Vision expresses the aspirations of } \\
\text { the Tongan people and the ultimate aims of all the development } \\
\text { efforts that will be undertaken during the Framework period. In } \\
\text { securing the vision, it is essential to create a Tonga where } \\
\text { enterprise can flourish, where opportunity exists for all, and } \\
\text { where Tongans have the confidence to face the challenges of a } \\
\text { global society. }\end{array}$ \\
\hline \multicolumn{2}{|c|}{ National Objectives } \\
\hline \multirow[t]{6}{*}{$\begin{array}{l}\text { Primary } \\
\text { Outcome }\end{array}$} & $\begin{array}{l}\text { Facilitate Community Development by involving district/village } \\
\text { communities in meeting their service needs. }\end{array}$ \\
\hline & $\begin{array}{l}\text { Support private sector growth through better engagement with } \\
\text { government, appropriate incentives and streamlining of rules } \\
\text { and regulations. }\end{array}$ \\
\hline & Facilitate continuation of Constitutional Reform. \\
\hline & $\begin{array}{l}\text { Maintain and develop infrastructure to improve the everyday } \\
\text { lives of the people. }\end{array}$ \\
\hline & $\begin{array}{l}\text { Increase performance of Technical Training Vocational } \\
\text { Education \& Training to meet the challenges of maintaining and } \\
\text { developing services and infrastructure. }\end{array}$ \\
\hline & $\begin{array}{l}\text { Integrate environmental sustainability and climate change into } \\
\text { all planning and executing of programs }\end{array}$ \\
\hline \multirow[t]{4}{*}{$\begin{array}{l}\text { Enabling } \\
\text { Themes }\end{array}$} & $\begin{array}{l}\text { Continue progress to smaller and more efficient government to } \\
\text { transfer resources to improved services and maintenance of } \\
\text { resources. }\end{array}$ \\
\hline & $\begin{array}{l}\text { Ensure State Owned Enterprises are accountable to government } \\
\text { as owner }\end{array}$ \\
\hline & $\begin{array}{l}\text { Improve the effectiveness of revenue collection to ensure a level } \\
\text { playing field and that services to the people can be appropriately } \\
\text { funded }\end{array}$ \\
\hline & $\begin{array}{l}\text { Ensure a more coordinated whole of government approach to } \\
\text { donor funding }\end{array}$ \\
\hline
\end{tabular}

\begin{tabular}{|l}
\hline Policy Area \\
Finance \\
Government Policy \\
Education and Training \\
Research \& Development \\
Physical Infrastructure \\
\end{tabular}

National Priority Implications
Financial packages and lending criteria being reviewed and re-designed to mutually benefit both consumer and lender.

Recommendations made in Volume 1 in relation to government policy being read in conjunction with the proposed Trade Policy Framework that it is consistent with the Strategic Development Plan 8 objectives.

Increased capital investment in the country's physical infrastructure, particularly transportation to the outer islands and extremely difficult to access areas.

Supporting the work of the World Bank and the Strategic Airport Development Plan.

Research and Development needs being identified.

Government programmes Education and training Abilities and knowledge to start up

\section{Government policy} Government programmes Commercial and service infrastructure

\section{Government policy} Physical infrastructure

Education and Training Commercial and services infrastructure Government programmes Education and Training Government policy

Government programmes

\section{Education and Training}

Government Policy

Government programmes
Increased government programmes aimed at introducing 'good governance principles' at local and regional governance and building local capability to participate in the overall decision making process. These outcomes will encourage entrepreneurial activity and meet the objectives of NSPF.

Specific education and training initiatives will help build capability in the identified deficient areas such as increasing the understanding of gaps in the market, as well as to learn strategies to fill these gaps.

Local knowledge is critical in understanding the service needs of the community i.e. at village and regional levels, particularly when considering physical and communication needs to improve access to rural and remote areas.

Research findings to be made available to necessary stakeholders in order to strengthen the work of National Economic

Development Council (NEDC) which is charged with the responsibility of stimulating economic growth by identifying, and

recommending to cabinet, policy initiatives for a private sector led economy. In particular to facilitate private sector initiatives in agriculture, fisheries, tourism and infrastructure.

Programmes to build capacity and capability within the public sector to provide improved services for the private sector. Support the political reform

Improved access by sea and air to outer and remote islands. Improved roads, basic utilities and waste disposal in rural areas and on outer islands. Increased telecommunication coverage. Support work already evident in Tonga in these areas carried out by joint and collaborative ventures between Tonga, NZ, and Australia.

Support work currently underway by other donors operating in Tonga for example, Asian Development Bank (ADB) and World Bank (WB) such as in the area of 'ease of doing business' as set out by the WB in the Doing Business indicators.

Provide opportunities for scholarships, apprenticeships and overseas internships.

Including more content in the primary and secondary curriculum.

Government driven policy that supports this initiative and drive it from within public sector.

NEDC including this priority in all of its training programmes aimed at private sector as good business practice

Ensure alignment and clear linking of all government and private programmes meet this theme

Ensure alignment and clear linking of all government and private programmes meet this theme.

New government policies designed to 'weed out' corruption as well as unfair and illegal practices

A centralized and effective system specifically for the purpose of monitoring projects, initiatives and programmes. 
